\title{
$\mathrm{B}$
}

ековой опыт отечественной дерматовенерологии. Этапы развития кожно-венерологической помощи населению (часть III)

Кубанова А. А. ${ }^{1}$, Мартынов А. А. ${ }^{1 *}$, Власова А. В. ${ }^{2}$

${ }^{1}$ Государственный научный центр дерматовенерологии и косметологии Министерства здравоохранения Российской Федерации

107076, Российская Федерация, г. Москва, ул. Короленко, д. 3, стр. 6

2 Первый МГМУ им. И.М. Сеченова Министерства здравоохранения Российской Федерации (Сеченовский университет) 119991, Российская Федерация, г. Москва, ул. Трубецкая, д. 8, стр. 2

Проведен анализ этапов фрормирования модели организации оказания кожно-венерологической помощи населению Российской Федерации за период с 1917 по 2017 год.

Ключевые слова: дерматовенерология, кожно-венерологический диспансер, врач-дерматовенеролог,

Великая Октябрьская социалистическая революция, Гражданская война, дерматомикозы, глубокие микозы, временные микологические стационары, стандарты медицинской помощи, лепра, лепрозории, косметология

Конфрликт интересов: авторы заявляют об отсутствии потенциального конфликта интересов, требующего раскрытия в данной статье.

Для цитирования: Кубанова А. А., Мартынов А. А., Власова А. В. Вековой опыт отечественной дерматовенерологии. Этапы развития кожно-венерологической помощи населению (часть III). Вестник дерматологии и венерологии. 2018;94(2):12-26. https://doi.org/10.25208/0042-4609-2018-94-212-26 


\section{A hundred years' experience in national dermatovenereology stages of organization of dermatovenereological care for the population (part III)}

Anna A. Kubanova ${ }^{1}$, Andrey A. Martynov ${ }^{1 \star}$, Anna V. Vlasova²

${ }^{1}$ State Research Center of Dermatovenereology and Cosmetology, Ministry of Health of the Russian Federation Korolenko str., 3, bldg 6, Moscow, 107076, Russian Federation

${ }^{2}$ I. M. Sechenov First Moscow State Medical University of the Ministry of Health of the Russian Federation (Sechenov University) Trubetskaya str., 8, bldg 2, Moscow, 119991, Russian Federation

The stages of the formation of a model for the organization of dermatovenereological care to the population of the Russian Federation for during the period from 1917 to 2017 were analyzed.

Keywords: dermatovenereology, dermatovenerologic dispensary, dermatovenerologist, the great October Socialist Revolution, Civil War, dermatomycosis, deep fungal infections, temporary mycological hospitals, standards of medical care, leprosy, leprosarium, cosmetology

Conflict of interest: the authors state that there is no potential conflict of interest requiring disclosure in this article.

For citation: Kubanova A. A., Martynov A. A., Vlasova A. V. A hundred years' experience in national dermatovenereology stages of organization of dermatovenereological care for the population (part III). Vestnik Dermatologii i Venerologii. 2018;94(2):12-26. https://doi.org/10.25208/0042-4609-2018-94-2-12-26 
VI. Особенности подходов к организации медицинской помощи при дерматомикозах

Наряду с дерматовенерологией в Российской Федерации активно развивалось несколько взаимосвязанных клинических направлений, на базе которых в результате были созданы новые специальности. Прежде всего это микология.

Целостной системы организации борьбы и профилактики микозов в дореволюционной России не существовало. Вместе с тем заболеваемость ими была очень высокой - ежегодно регистрировалось около 3 тыс. новых случаев трихофитии.

Отдельными научными коллективами проводился поиск и идентификация возбудителей грибковых заболеваний, совершенствовались методы диагностики, лечения. В частности, в 1902 г. был предложен метод эпиляции рентгеновскими лучами. В последующем метод неоднократно совершенствовался (трехпольная, четырехпольная или дробная эпиляция).

Предложения видных ученых того периода о необходимости изоляции больных в «хороших и дешевых больницах в городах и в деревнях», а также об организации массовых профрилактических осмотров населения, особенно детей, поддерживались, но не были реализованы.

После Великой Октябрьской социалистической революции организация борьбы с дерматомикозами базировалась на диспансерном методе работы (выявление источника заражения, обследование членов семьи и лиц, имевших контакт с больными, контроль за аккуратностью лечения и т.д.).

Основные научные исследования были сосредоточены на эпидемиологии микозов, создании отечественной классификации, повышении доступности эфрфективных методов лечения. Было установлено, что в Российской Федерации преобладали антропофильные (фиолетовый и кратеровидный) трихофитоны; на втором месте был пушистый микроспорум.

Начиная с 1920 г. ффункции организационно-методического центра по борьбе с дерматомикозами выполнял Первый микологический диспансер в г. Москве.

С 1921 г. начали создаваться специальные детские дома с целью ликвидации дерматомикозов в детских коллективах.

По результатам проведенного в 1923 г. Всероссийского совещания по вопросам борьбы с микозами:

- создавались временные микологические стационары;

- внедрялись передвижные рентгено-эпиляционные установки;

- проводились экспедиции в сельские местности (в Туркменскую ССР, Узбекскую ССР и др.);

- обеспечивался санитарный надзор за парикмахерскими, уничтожались бездомные животные;

- проводилась широкая санитарно-просветительная работа, включая профилактику микозов на различных производствах;

- широко внедрялась люминесцентная диагностика микроспории.

- в отдельных республиках создавался особый тип учреждений для больных микозами - фавозории (например, в Азербайджанской ССР в 1937 г. было создано 18 подобных учреждений).

В 1925 г. в г. Москве был открыт первый в стране микологический диспансер.
К началу 1930-х годов было обеспечено резкое снижение заболеваемости микозами на всей территории страны.

В 1931 г. была предложена первая отечественная классисрикация дерматомикозов (П. А. Черногубов). Он различал три группы: зпидермомикозы, поверхностные и глубокие дерматомикозы.

Однако наибольшее распространение получила классификация, предложенная в 1963 г. А. М. Ариевичем. В ней учитывался как ботанико-этиологический принцип (локализация гриба в том или ином слое кожи или органе), так и ответная реакция организма на внедрение патогенного гриба.

В 1939 г. был введен учет больных дерматомикозами на основе «обязательных извещений», а в 1943 г. — карточный учет дерматомикозами.

К 1953 г. заболеваемость дерматомикозами в Российской Федерации по сравнению с ранним послевоенным периодом была снижена вдвое.

Во многом этому также способствовал опыт организации временных микологических стационаров. Как правило, они организовывались на базе участковых больниц, мощностью от 15 до 30 коек. Кожно-венерологическая помощь больным грибковыми заболеваниями в условиях временных микологических стационаров осуществлялась персоналом участковой больницы, прошедшим краткосрочную (в течение 10 дней) подготовку. Оказание помощи проводилось под контролем врача КВД. Основными пациентами временных микологических стационаров (до $90 \%$ ) становились дети в возрасте до 15 лет с проявлениями поверхностной трихосиити волосистой части головы. В результате организации временных микологических стационаров до 97 \% случаев лечения было полностью законченными на месте [1].

В 1963 г. в Российской Федерации микроспория волосистой части головы регистрировалась более чем в половине случаев от общего числа заболевших грибковыми заболеваниями кожи. Микроспория, обусловленная ржавым микроспорумом, весьма контагиозная, проникшая на территорию страны во время Великой Отечественной войны и давшая большие эпидемические вспышки, была ликвидирована. Фавус и глубокие микозы встречались относительно редко.

Регламентация деятельности отделений и кабинетов микологии осуществлялась нормативными правовыми актами и методическими документами Минздрава России, организация помощи - в соответствии со стандартами медицинской помощи [2].

К середине 1980-х годов сложилась напряженная ситуация с организацией микологической помощи населению, что было обусловлено следующими моментами:

- значительно выросли показатели заболеваемости микозами стоп и кистей, которые превышали уровень заболеваемости всеми другими дерматофитиями вместе взятыми и способствовали значительным трудопотерям в группе инфекционных заболеваний кожи. При этом отсутствовала соответствующая официальная статистическая отчетность;

- отмечалось неудовлетворительное санитарно-гигиеническое содержание бань, душевых, бассейнов и других мест общественного пользования;

- мероприятия по снижению заболеваемости трихофритией животных частного сектора практически не проводились. 
В этой связи Минздравом СССР были даны рекомендации по организации на базе кожно-венерологических диспансеров «Микологических центров». Однако из-за последовавшего распада страны не все рекомендации были осуществлены.

В настоящее время амбулаторная помощь больным микозами осуществляется, как правило, в микологических кабинетах кожно-венерологических диспансеров (в 2002 г. их было 87); для оказания стационарной помощи больным микозами в 2002 г. было развернуто 1239 круглосуточных коек.

Культуральная диагностика микозов остается золотым стандартом при определении возбудителей микозов, однако, по результатам выборочных исследований, проводится не во всех лабораториях.

В 2002 г. только микроскопическая диагностика микозов проводилась в 850 лабораториях, культуральная в 95 лабораториях (рис. 1).

С середины 1950-х годов в арсенале врачей появились первые специфические антимикотики: гризеофульфрин (синтезирован в 1958 г.) и амфротерицин В (1956 г.). В 1970-х гг. были внедрены в практику производные имидазола - антимикотики II поколения - клотримазол

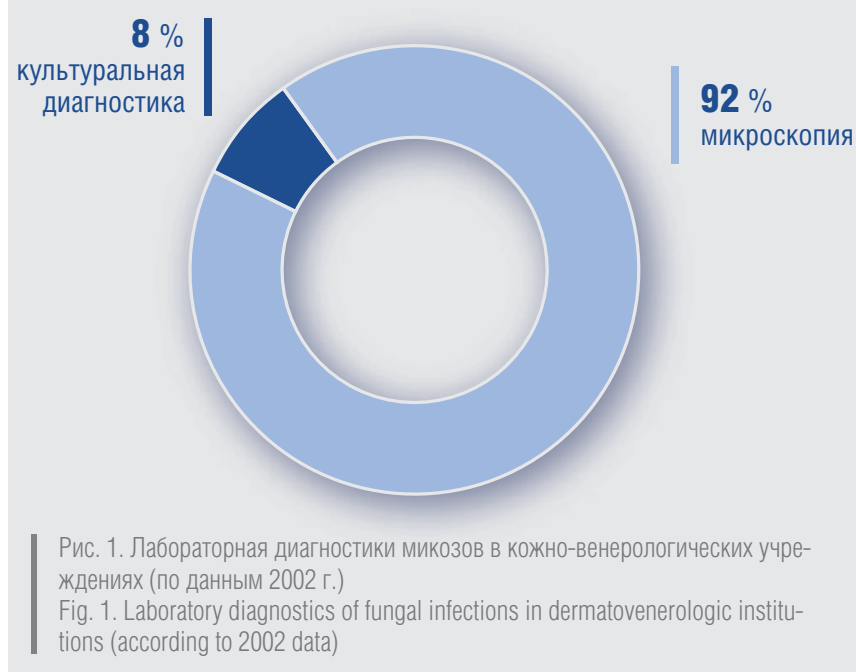

(1969 г.), миконазол, кетоконазол (1978 г.) и др.; в 1990-е годы - антимикотики III поколения (производные триазола) - итраконазол (1980 г.), фрлуконазол (1982 г.) и аллиламины - тербинафиин, нафртифин.

В настоящее время внедряются антимикотики IV и V поколений: липосомальные формы полиеновых антибиотиков (амфотерицина В и нистатина), производные триазола - вориконазол (1995 г.), позаконазол (2007 г.) и др.

Научные исследования в области глубоких микозов длительное время проводились в Институте медицинской паразитологии и тропической медицины им. Е. И. Марциновского (г. Москва). В период 1932-1966 гг. в институте функционировало отделение патогенных грибков; с 1967 по 1992 г. - отдел по изучению клиники, патогенеза и разработке диагностики и лечения глубоких микозов. В настоящее время вопросы глубоких микозов прорабатываются в г. Москве на базе Центра глубоких микозов городской клинической больницы № 81 Департамента здравоохранения г. Москвы.

Крупным центром в области изучения глубоких микозов является Санкт-Петербургский научно-исследовательский институт медицинской микологии имени П. Н. Кашкина.

В 1958 г. в Санкт-Петербурге была создана проблемная микологическая лаборатория; в 1964 г. - первая микологическая клиника. В 1970 г. указанные подразделения были объединены в Научно-исследовательский отдел глубоких микозов с клиникой на 60 коек. Отдельное здание было построено к 1982 г.

С 1983 г. на базе отдела был организован Всесоюзный центр Минздрава СССР по глубоким микозам, который координировал научные исследования в области глубоких микозов и микогенной аллергии [3]. Всемирной организацией здравоохранения данный центр был определен в качестве Международного центра по глубоким микозам [4].

C 1987 г. на базе центра создана коллекция патогенных грибов. Коллекция включает свыше 1200 культур условно-патогенных и патогенных грибов. Среди культур значительную часть составляют стандартные (референтные) штаммы и виды, полученные из ряда отечественных и зарубежных коллекций микроскопических грибов.

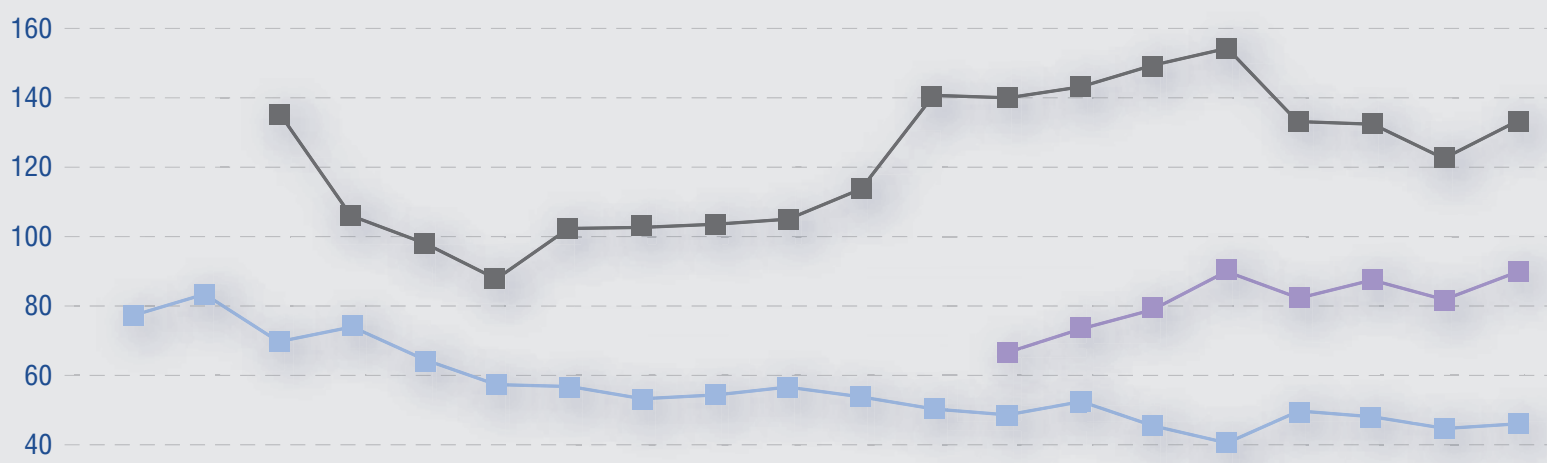

20

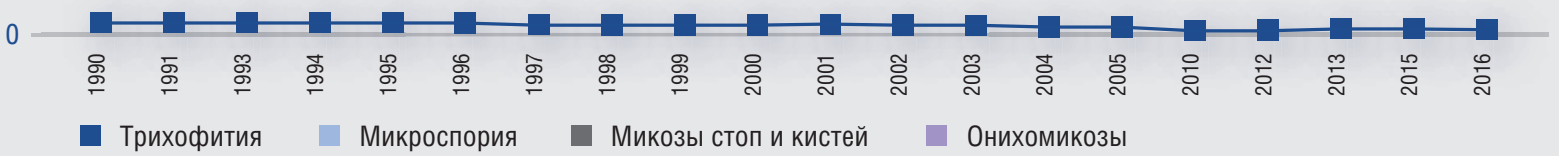

Рис. 2. Динамика заболеваемости населения Российской Федерации дерматомикозами за период 1990-2016 годы (на 100 тыс. населения) Fig. 2. Incidence dynamics of dermatomycosis in the Russian Federation over the 1990-2016 period (per 100,000 population) 
В период 1991-1998 гг. центр был реорганизован в микологический центр Санкт-Петербургской академии последипломного образования. С 1998 г. центр преобразован в Научно-исследовательский институт медицинской микологии имени П. Н. Кашкина.

С 1999 г. издается ежеквартальный научно-практический журнал «Проблемы медицинской микологии».

С 2004 г. присуждается премия имени профессора П. Н. Кашкина «За выдающиеся заслуги в развитии отечественной микологии».

В период 2003-2015 гг. на базе данного института осуществлялась подготовка специалистов по двум новым специальностям: «Клиническая микология» и «Лабораторная микология» (в 2015 г. данные специальности исключены из номенклатуры специалистов) [5, 6].

В 2004 г. на базе центра создан Научно-методический микологический центр Минздрава России [7], где оказывается медицинская помощь больным инвазивными микозами (аспергиллез, кандидоз, криптококкоз, зигомикоз, споротрихоз, эндемичные микозы и др.), микогенной аллергией (аллергический бронхолегочный аспергиллез и пр.) и аспергилломой.

С 2002 г. были внедрены новые фрормы статистического учета микозов. В настоящее время проводится регистрация трихофитии, микроспории, микозов стоп и кистей, включая онихомикоз (динамика показателей заболеваемости приведена на рис. 2).

\section{VII. Организационные аспекты оказания медицинской помощи больным лепрой}

Несмотря на то что лепра является инфекционным заболеванием, врачи-дерматовенерологи, как правило, одними из первых сталкиваются с начальными проявлениями болезни. Именно поэтому развитие учения о лепре в стране неразрывно связано с дерматовенерологией.

До революции лепрой занимались общественные благотворительные комитеты и различные неспециализированные инстанции, в том числе военные ведомства. Были выявлены эндемичные по лепре районы, где и создавались лепрозории.

Регион Нижнего Поволжья являлся крупнейшим в России очагом лепры, на долю которого в разные периоды приходилось от 30 до 60 \% всех зарегистрированных на территории Российской Федерации больных лепрой.

К 1917 г. было создано 14 лепрозориев, которые содержались за счет казны. Десять из лепрозориев располагались в Астраханской, Оренбургской и Казанской губерниях, один - в Ингерманландии, один - в Туркестанском крае и два - в Польше. Учет больных лепрой, к сожалению, практически не осуществлялся.

В период революции и Гражданской войны больные лепрой либо погибли, либо разбежались.

Планомерная работа по борьбе с лепрой в Российской Федерации начала осуществляться с 1923 г. благодаря прежде всего улучшению материально-технического обеспечения всех лепрозориев за счет бюджетного фринансирования [8]. Кроме того, были предусмотрены следующие меры:

- введение учета больных лепрой;

- создание трудового образа жизни в лепрозориях;

- страхование больных лепрой;

- предоставление льготного проезда больным лепрой;

- предотвращение въезда больных лепрой из-за границы;
- заключение договоров по борьбе с лепрой с другими государствами.

В первые годы советской власти вопросы лепры активно разрабатывались специалистами Института медицинской паразитологии и тропической медицины им. Е. И. Марциновского. В 1924 г. при институте было организовано отделение (сектор) лепрологии, который в 1953 г. был передан в состав Центрального научно-исследовательского кожно-венерологического института Минздрава СССР (в 1985 г. отделение было закрыто).

В 1947 г был создан Всесоюзный научно-исследовательский институт по изучению лепры на базе Астраханского клинического лепрозория [9].

Больные лепрой в принудительном порядке находились в лепрозории пожизненно. История болезни на каждого больного лепрой велась до момента смерти. Успешно проходящим лечение больным в целях социальной адаптации один-два раза в год предоставлялся отпуск (продолжительностью до 20 дней), в течение которого они могли покинуть территорию лепрозория [10]. При лепрозориях были организованы кладбища для больных лепрой, отдельные из которых действуют до настоящего времени.

К 1959 г. появились новые научные данные о лепре и эффективные методы борьбы с ней, в частности были внедрены сульфоновые препараты, изготовленные в СССР, были разработаны новые методы иммунобиологической и медикаментозной профилактики заболевания [11, 12].

Указанные меры обеспечивали «выздоровление» больных лепрой после 2-8 лет лечения, способствовали снижению средней продолжительности курсового лечения больных лепрой до трех лет.

В соответствии с достижениями медицины того периода мероприятия по борьбе с лепрой обязательно были двухкомпонентные и включали как медицинские, так и социальные аспекты. Они были призваны обеспечивать своевременное выявление больных лепрой, полноценное их лечение, последующее диспансерное наблюдение, а также соответствующие меры профилактики. В этих целях регулярно обновлялись инструкции по борьбе с лепрой, а также устанавливались меры социальной поддержки данной группы больных [13-15]. Больным лепрой, выписанным из лепрозориев, назначались и выплачивались ежемесячные пособия (пенсии), предоставлялись без оплаты лекарственные препараты для лечения, компенсировались транспортные расходы к месту лечения и обратно [16]. В лепрозориях организовывались лечебно-трудовые мастерские [17].

К 1970-м годам в Российской Федерации, несмотря на то что особенности эпидемиологического процесса при лепре до конца не были раскрыты, было обеспечено резкое снижение заболеваемости лепрой до спорадических случаев $[11,18]$.

В настоящее время распространенность лепры в Российской Федерации характеризуется неравномерностью и в целом составляет 0,05:10000 населения. По экспертным оценкам, общее число больных лепрой в стране в настоящее время не превышает 250 человек, большая часть которых проживают на территории Астраханской области.

Эндемические очаги лепры сохраняются в Нижнем Поволжье и на Северном Кавказе. На эти регионы приходится в настоящее время более 90 \% всех зарегистрированных больных. Основными зонами распространения лепры являются Астраханская область, Ставропольский 


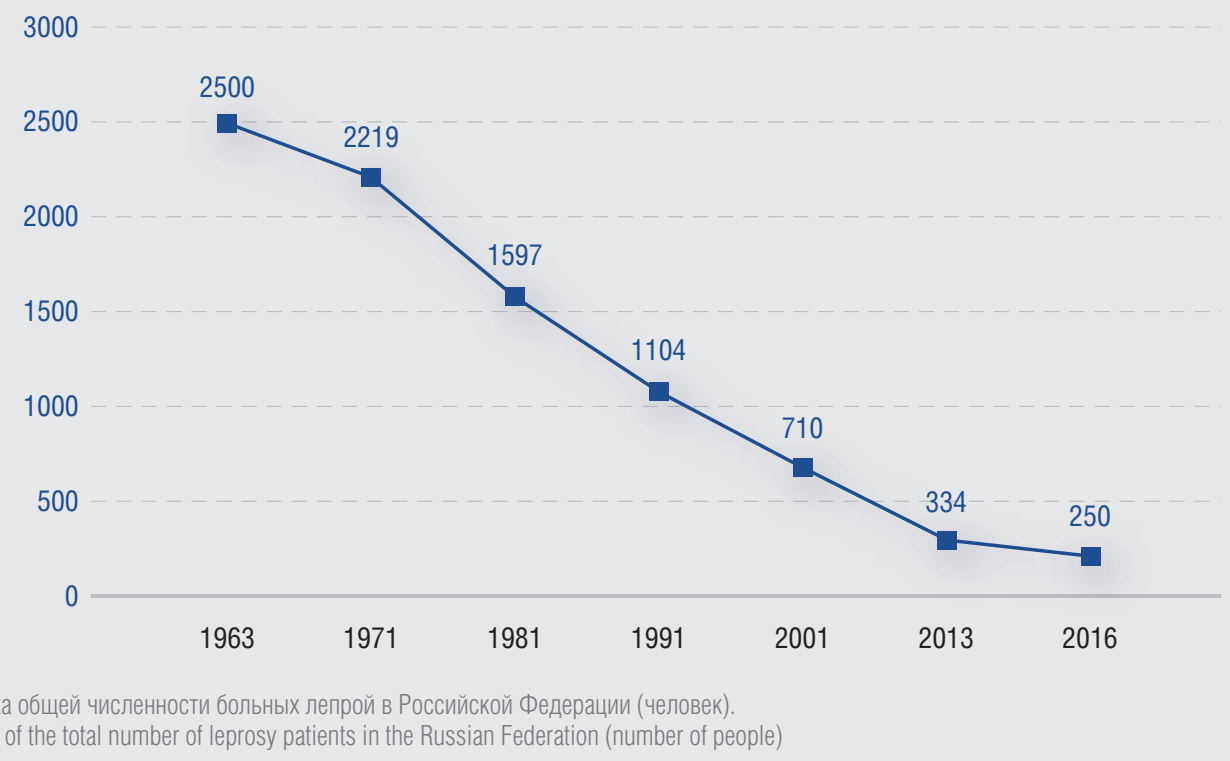

Рис. 3. Динамика общей численности больных лепрой в Россииской Федерации (человек).
Fig. 3. Dynamics of the total number of leprosy patients in the Russian Federation (number of people)

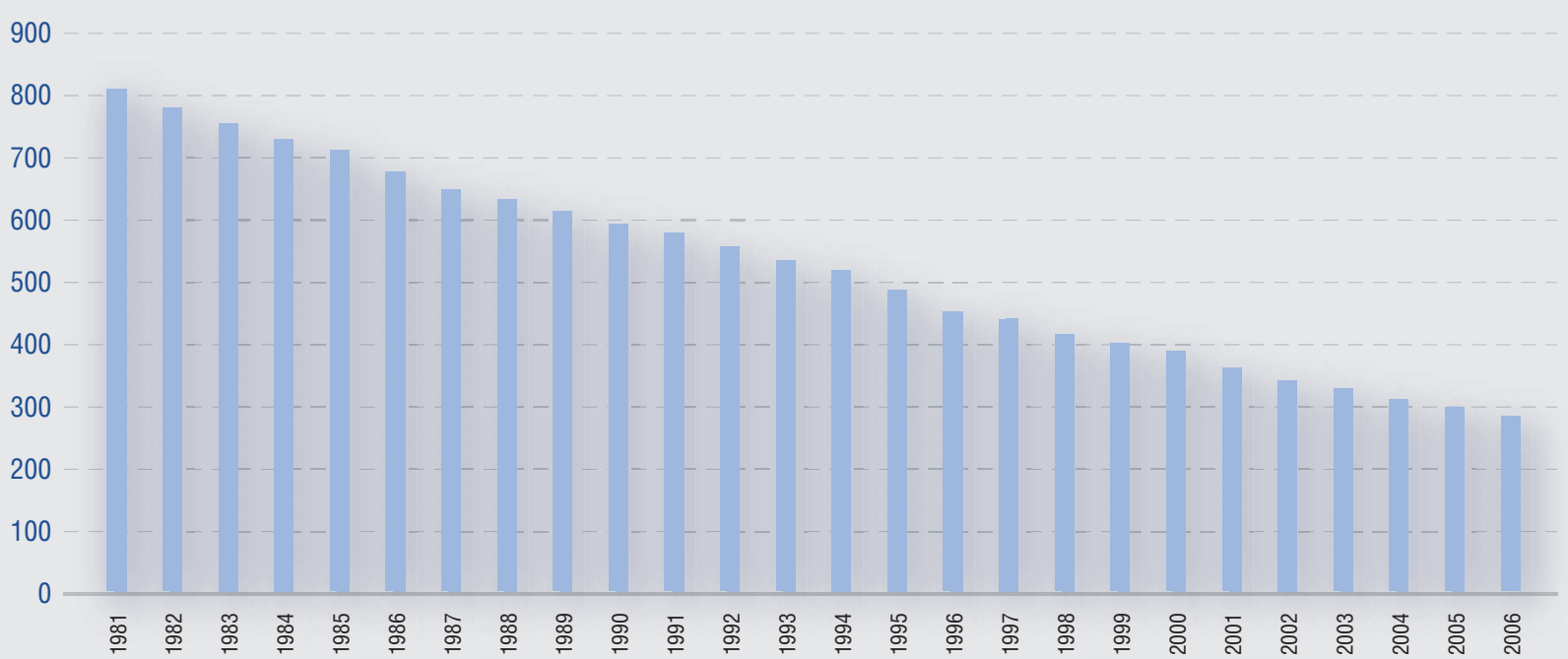

Рис. 4. Динамика общей численности больных лепрой в Астраханской зоне за 1981-2005 гг. (человек)

Fig. 4. Dynamics of the total number of leprosy patients in the Astrakhan zone for 1981-2005. (number of people)
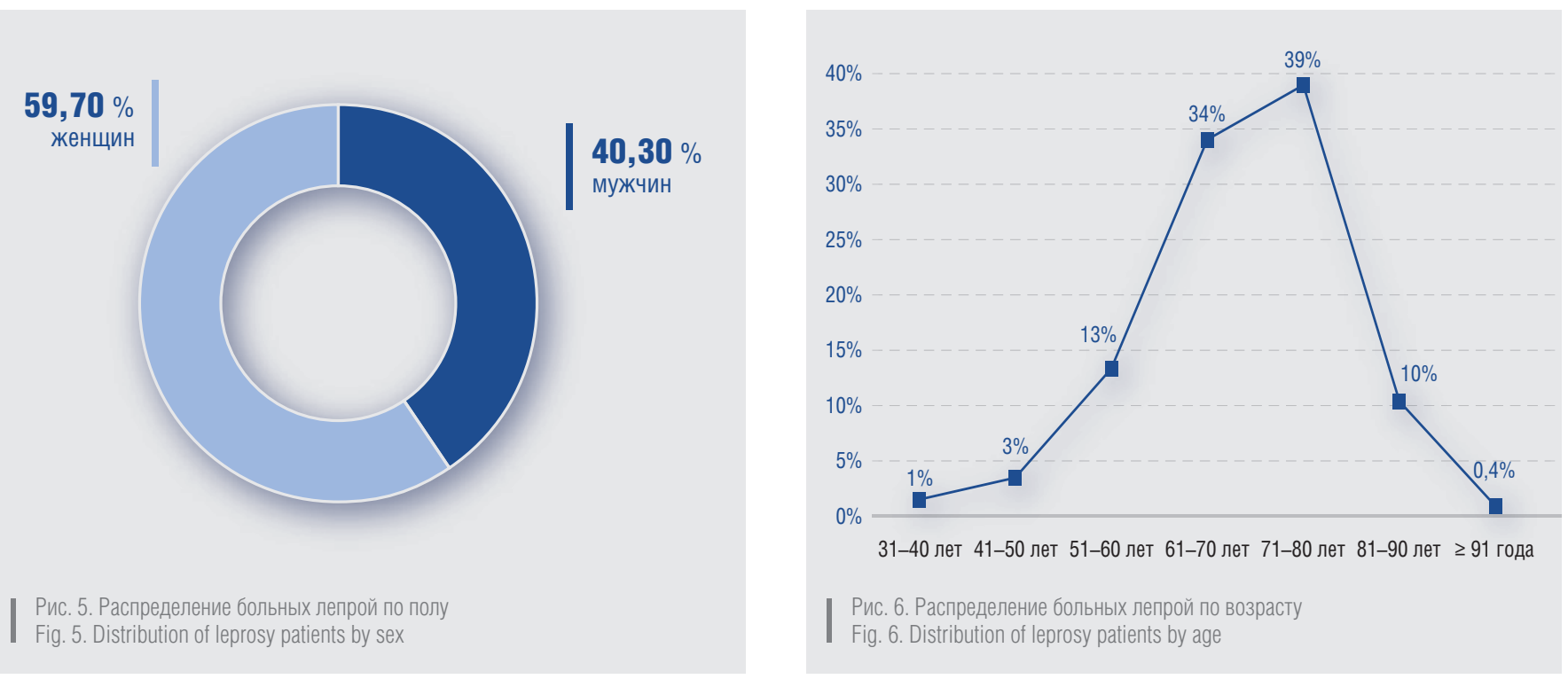

Вестник дерматологии и венерологии. 2018;94(2):12-26 
край, республики Северного Кавказа, Краснодарский край, Ростовская область.

По данным Научно-исследовательского института по изучению лепры Минздрава России, первичная заболеваемость в зоне его обслуживания носит спорадический характер. За период 1981-2005 гг. вновь выявлено 40 больных лепрой. По состоянию на 1 сентября 2006 г. состояло на учете 278 больных лепрой; также наблюдались 193 человека, имевших тесный семейный контакт с больными лепрой (рис. 4-6).

Таким образом, первичная заболеваемость лепрой снизилась до единичных, спорадических случаев и, как следствие, уменьшилось число состоящих на учете больных. Одновременно значительно увеличилась средняя продолжительность и улучшилось качество жизни больных лепрой.

Это привело к сокращению количества лепрозориев. На территории СССР всего было создано 20 лепрозориев. Во многих зарубежных странах к настоящему моменту лепрозории, по сути, прекратили свое существование. В Российской Федерации продолжают функционировать 4 лепрозория, в том числе:

- Научно-исследовательский институт по изучению лепры Минздрава России (г. Астрахань);

- Сергиево-Посадский фрилиал Государственного научного центра дерматовенерологии и косметологии Минздрава России (Московская область);

- Терский лепрозорий (Ставропольский край);

- лепрозорий департамента здравоохранения Краснодарского края (Краснодарский край).

\section{VIII. Косметология как отдельная специальность}

Другим направлением развития дерматовенерологии стало выделение в отдельную специальность косметологии.

В дореволюционной России, так же как и намного позже, в стране функционировало большое число частных косметических салонов и кабинетов, где проводились косметические процедуры и массажи.

Первый в России научно-практический центр косметологии - Институт врачебной косметологии доктора Остроумова - был организован до революции (в 1908 г.).

В начале XX века в стране были опубликованы первые отечественные руководства по косметологии, издавался ряд специализированных журналов, посвященных вопросам косметологии, в частности:

- на протяжении 1907 г. - еженедельный специализированный литературно-научный журнал;

- в 1908-1910 гг. дважды в месяц выходил журнал «Косметика».

После Великой Октябрьской социалистической революции вопросы косметологии и обращения косметических препаратов строго нормировались государством.

В 1930 г. кооперативной организацией Мосгорбытпромсоюза была организована «Московская врачебнокосметическая лечебница», которая до нашего времени дошла в виде «Института красоты» на Арбате».

В 1937 г. в г. Москве при Министерстве пищевой промышленности СССР был организован Институт красоты и здоровья, а в городах Сочи и Кисловодске открыты его фрилиалы. В период Великой Отечественной войны институт временно приостанавливал свою деятельность. После окончания войны институт был переведен в ведение Минздрава СССР и получил новое наименование -
Институт врачебной косметики. К 1966 г. институт был реорганизован в Московский научно-исследовательский институт косметологии Минздрава РСФСР, и, по сути, это был крупнейший организационно-методический центр в стране в области косметологии.

К началу 1975 г. в СССР было около 160 косметологических учреждений (5 поликлиник, 19 врачебно-косметологических лечебниц, 134 кабинета).

Вместе с тем в стране сохранялось неудовлетворительное состояние косметологической помощи населению. В целях исправления ситуации в начале 1960-х годов Минздравом СССР принимались решительные меры к развитию врачебной косметики во всех союзных республиках. Была поставлена задача, чтобы в каждом областном центре КВД оказывал врачебную косметологическую помощь [11]. Организовывать косметологическую помощь предлагалось на базе отделов косметологии и фризиотерапии в кожно-венерологических институтах, возложив на них разработку научных проблем в этой области, лечебную помощь населению, методическое руководство лечебной помощью в прикрепленных к ним областях и городах. Также предлагалось создание отдела косметологии в Центральном научно-исследовательском кожно-венерологическом институте Минздрава СССР. Одновременно была поставлена задача оборудовать кабинеты косметологии соответствующей аппаратурой и инструментарием, а также срочно организовать обучение дерматологов и фризиотерапевтов соответствующим методам лечения [19].

К началу 1980-х годов ситуация по развитию косметологической помощи, по сути, не претерпела положительных изменений. В ряде республик и областей косметологические лечебницы и кабинеты отсутствовали. В отдельных городах врачебно-косметологическая помощь оказывалась в парикмахерских и домах быта, что считалось недопустимым.

Условия работы косметологических лечебниц и кабинетов нередко не соответствовали современным требованиям. Они размещались в неприспособленных помещениях, были недостаточно оснащены медицинским оборудованием и необходимым инструментарием.

Отсутствовала единая методика работы, подготовка новых кадров носила случайный характер; в отдельных лечебницах и кабинетах работали врачи без специальной подготовки по косметологии, дерматовенерологии, хирургии, несмотря на имеющиеся возможности для проведения специализации [20].

В 1982 г. Минздравом СССР был предпринят ряд новых шагов по развитию косметологической помощи. В частности, были утверждены положения о косметологической лечебнице, а также о врачах-специалистах, работающих в ней, и ее руководителе. Одновременно было осуществлено нормирование оказания косметологической помощи, включая штатные нормативы и нагрузку на врачей [21]. Однако нововведения не смогли обеспечить должного развития косметологии.

В конце XX века ситуация по организации оказания косметологической помощи населению вновь оказалась в центре внимания.

К 1989 г. в Российской Федерации фрункционировало 110 косметологических поликлиник, лечебниц, кабинетов (в том числе в г. Москве - 2, в Санкт-Петербурге - 1); В 11 регионах их не было; всего в них работало около 2200 косметологов, в том числе 700 врачей. 
К тому времени Институт врачебной косметики в результате многочисленных реорганизаций превратился, по сути, в чисто коммерческое предприятие [22, 23].

При этом востребованность косметологической помощи сохранялась на достаточно высоком уровне, а ее качество и доступность неуклонно снижались (табл. 1) [24].

Вплоть до 2005 г. косметологическая помощь населению Российской Федерации обеспечивалась специализированными медицинскими отделениями системы Министерства здравоохранения (лечебницы, кабинеты), косметическими кабинетами при учреждениях бытового и коммунального хозяйства - парикмахерские салоны, дома быта, бани, гостиницы.

Таблица 1. Результаты выборочных исследований по востребованности косметологической помощи

Table 1. Results of sample studies on the population's demand for cosmetic skin care

\begin{tabular}{ccc}
\hline & 1980 год & 2001 год \\
\hline Распределение пациентов по социальным группам & 3,1 \\
\hline Рабочие & 13 & 91,9 \\
\hline Служащие & 64 & 3,5 \\
\hline Учащиеся & 23 & 1,5 \\
\hline Неработающие & 0,1 & \\
\hline \multicolumn{3}{c}{ Распределение пациентов по полу } \\
\hline Женщины & 82 & 41 \\
\hline Мужчины & 18 & \\
\hline Распределение пациентов по возрасту & 8,3 \\
\hline 15-20 лет & 16 & 9,8 \\
\hline $21-30$ & 39 & 32,9 \\
\hline $31-40$ & 26 & 23,7 \\
\hline $41-50$ лет & 12 & 25,3 \\
\hline Старше 50 лет & 7 &
\end{tabular}

С середины 1990-х годов в Российской Федерации было введено лицензирование всех медицинских учреждений независимо от форм их собственности. Само лицензирование подразумевало выдачу государственного разрешения на осуществление определенных работ и услуг [25].

При этом возникли значительные трудности отнесения косметологических работ и услуг к различным видам экономической деятельности, осуществляемым как медицинскими организациями, так и предприятиями бытового обслуживания (в частности, банями и парикмахерскими), которым не требовалось получения лицензии.

По результатам плановых контрольных мероприятий в 2005 г. на территории г. Москвы при организации оказания косметологической помощи более чем в $80 \%$ случаев выявлялись значимые нарушения [26]. Среди нарушений, выявленных в ходе осуществления плановых проверок, наиболее типичными были [27]:

- отсутствие лицензии как на медицинскую деятельность, так и на продажу косметологических препаратов;

- использование несертифицированных косметологических препаратов;
- использование медицинских технологий, не зарегистрированных в установленном порядке («плацентарная терапия», «диплоидные клетки человека», омоложение собственными «аутологичными» клетками пациента, мезолифтинг, применение фиибробластов при мезотерапии, прессотерапия и др.);

- использование коммерческих наименований для большинства медицинских программ (технологий), что не позволяет оценить их медицинскую значимость («платиновое тело», «ионный дом», «минеральная гипсовая программа» и т. д.);

- нарушение совместимости используемых методик и соответствующих им косметических препаратов;

- отсутствие документов о специальной подготовке специалистов;

- несоответствие организационно-технических, санитарно-эпидемиологических, материально-технических и противопожарных требований условиям осуществления медицинской деятельности.

Начавшаяся в 2004 г. административная реформа повлекла за собой модернизацию системы организации оказания медицинской помощи, в том числе косметологической. Наиболее существенные изменения коснулись статуса косметологических лечебниц, которых не оказалось в новой номенклатуре медицинских учреждений [28, 29].

В связи с этим экспертным сообществом неоднократно предлагалось ввести специальности «врача-косметолог» и «врач - пластический хирург».

Среди контраргументов высказывались сложности определения предмета деятельности таких специальностей, а также возможная «зауженность» врачей, что могло привести к снижению качества оказываемой ими медицинской помощи.

В целях унифокиции подходов при лицензировании медицинской деятельности были четко определены требования к образованию медицинского персонала в области косметологии и пластической хирургии, а также сорормирован перечень работ и услуг по косметологии, относящихся непосредственно к медицинской деятельности [30]. Данный перечень включал 65 методик, используемых при оказании врачебной косметологической помощи (30 \% из них относились к косметологии хирургической, $70 \%$ - к терапевтической).

В апреле 2009 г. Минздравсоцразвития России введена новая специальность, требующая дополнительной подготовки, - «косметология» [31]. С 2015 г. косметология была выделена в отдельную специальность [32].

Организационно-методическое руководство деятельностью в области косметологии осуществляется с 2010 г. Государственным научным центром дерматовенерологии и косметологии [33]. При этом функционал главного косметолога Российской Федерации возложен на главного дерматовенеролога страны [34].

С 2010 г. действует программа дополнительного профессионального образования по специальности «косметология». В соответствии с современными требованиями, врач-косметолог - это лицо с высшим медицинским образованием (специалитет по одной из специальностей: «Лечебное дело», «Педиатрия»), прошедший профессиональную переподготовку по специальности «Косметология» при наличии подготовки в интернатуре/ординатуре по специальности «Дерматовенерология», а также повышение квалификации не реже одного раза в 5 лет в течение всей трудовой деятельности [35]. 
Таблица 2. Сведения об организациях, оказывающих косметологическую помощь населению Российской Федерации (по данным Росздравнадзора по состоянию на ноябрь 2017 г.) Table 2. Information on organizations providing cosmetic skin care to the RF population (according to Roszdravnadzor as at November, 2017)

\begin{tabular}{cccccccc}
\hline & \multicolumn{2}{c}{ Государственные организации } & \multicolumn{2}{c}{ Частные организации } & \multicolumn{2}{c}{ BCEГО } \\
\cline { 2 - 8 } & организации & объекты & организации & объекты & организации & объекты \\
\hline Амбулаторные условия & 473 & 653 & 8814 & 9615 & 9287 & 10268 \\
\hline Стационарные условия & 33 & 38 & 81 & 174 & 184 & 128 \\
\hline Прочее & 19 & 28 & 165 & 90 & 202
\end{tabular}

Таблица 3. Структура организаций, оказывающих косметологическую помощь населению Российской Федерации, в зависимости от места расположения объекта деятельности (по данным Росздравнадзора по состоянию на ноябрь 2017 г.)

Table 3. Structure of organizations providing cosmetic skin care to the RF population, depending on their location (according to Roszdravnadzor as at November, 2017)

\begin{tabular}{|c|c|c|c|c|c|c|}
\hline & \multicolumn{2}{|c|}{ Государственные организации } & \multicolumn{2}{|c|}{ Частные организации } & \multicolumn{2}{|c|}{ ВСЕГО } \\
\hline & организации & объекты & организации & объекты & организации & объекты \\
\hline \multicolumn{7}{|c|}{ Амбулаторные условия } \\
\hline Центральный Ф0 & 161 & 239 & 3591 & 3850 & 3752 & 4089 \\
\hline Северо-Западный Ф0 & 81 & 96 & 1284 & 1435 & 1365 & 1531 \\
\hline Южный Ф0 & 37 & 46 & 721 & 797 & 758 & 843 \\
\hline Приволжский Ф0 & 77 & 118 & 1263 & 1384 & 1340 & 1502 \\
\hline Уральский Ф0 & 36 & 46 & 612 & 685 & 648 & 731 \\
\hline Сибирский Ф0 & 39 & 52 & 784 & 867 & 823 & 919 \\
\hline Северо-Кавказский Ф0 & 21 & 25 & 215 & 227 & 236 & 252 \\
\hline Дальневосточный Ф0 & 21 & 31 & 344 & 370 & 365 & 401 \\
\hline \multicolumn{7}{|c|}{ Стационарные условия } \\
\hline Центральный Ф0 & 5 & 5 & 34 & 38 & 39 & 43 \\
\hline Северо-Западный Ф0 & 11 & 12 & 17 & 17 & 28 & 29 \\
\hline Южный Ф0 & 5 & 5 & 5 & 6 & 10 & 11 \\
\hline Приволжский Ф0 & 8 & 10 & 6 & 7 & 14 & 17 \\
\hline Уральский Ф0 & 0 & 0 & 8 & 11 & 8 & 11 \\
\hline Сибирский Ф0 & 0 & 0 & 7 & 7 & 7 & 7 \\
\hline Северо-Кавказский Ф0 & 1 & 1 & 2 & 2 & 3 & 3 \\
\hline Дальневосточный Ф0 & 3 & 5 & 2 & 2 & 5 & 7 \\
\hline \multicolumn{7}{|c|}{ Прочее } \\
\hline Центральный Ф0 & 6 & 10 & 74 & 77 & 80 & 87 \\
\hline Северо-Западный Ф0 & 3 & 3 & 36 & 37 & 39 & 40 \\
\hline Южный Ф0 & 3 & 3 & 10 & 12 & 13 & 15 \\
\hline Приволжский Ф0 & 2 & 4 & 25 & 25 & 27 & 29 \\
\hline Уральский Ф0 & 1 & 1 & 10 & 10 & 11 & 11 \\
\hline Сибирский Ф0 & 1 & 1 & 6 & 7 & 7 & 8 \\
\hline Северо-Кавказский Ф0 & 1 & 4 & 2 & 3 & 3 & 7 \\
\hline Дальневосточный Ф0 & 2 & 2 & 2 & 3 & 4 & 5 \\
\hline
\end{tabular}

В 2012 г. был утвержден порядок оказания медицинской помощи населению по профилю «Косметология» [36], которым определены современные требования к организации соответствующей медицинской помощи (этапы оказания медицинской помощи; требования к персоналу, материально-техническому обеспечению и организации деятельности).
Формирование нормативной правовой базы в области косметологии во многом способствовало легализации данного направления экономической деятельности и обеспечило динамичное развитие специальности.

По экспертным оценкам [37], в 2016 г. в Российской Федерации 33,8 тысячи косметологов оказывали какие-либо косметологические услуги, включающие, помимо 
инъекций, дермабразии, процедуры аппаратной косметологии, пилинги и другие врачебные манипуляции, из них:

- более 80 \% практикуют биоревитализацию и мезотерапию;

- 50-60 \% - контурную пластику и ботулинотерапию;

- 30 \% - нитевой лифтинг и армирование.

Оказание косметологической помощи осуществляется преимущественно в амбулаторных условиях. По состоянию на ноябрь 2017 г., спустя 100 лет после Великой Октябрьской социалистической революции, соответствующая лицензия была выдана 9287 организациям, которые осуществляли такие работы на 10268 объектах (табл. 2). В структуре косметологических организаций доля государственных не превышает $6 \%$.

При этом наибольшее число косметологических организаций расположено в Центральном федеральном округе, в структуре которого лидирует г. Москва (табл. 3).

Одним из косвенных индикаторов состояния косметологической помощи в стране являются объемы продаж косметологических инъекционных продуктов. По экспертным оценкам, в 2015 г. весь рынок таких закупок оценивался на уровне 8,7-11 млрд рублей. Прогноз на 2016 г. превзошел все ожидания и составил около 36,8 млрд рублей. Всего с применением перечисленных видов косметологической продукции в 2016 г. было проведено более 12 млн процедур общей стоимостью 104,1 млрд рублей.

Таким образом, Российская Федерация стала одним из самых крупных национальных рынков по объемам продаж косметологических инъекционных продуктов, а также подготовки соответствующих специалистов. Согласно прогнозным оценкам, в период до 2020 г. Российская Федерация может занять до 20 \% в мировой индустрии косметологических инъекций.

Также следует упомянуть, что за прошедшие 100 лет количество журналов по вопросам красоты и здоровья увеличилось в разы. В настоящее время в Российской Федерации издается более 20 периодических изданий по вопросам косметологии. Среди них есть как узкопрофильные научные журналы («Вестник дерматологии и венерологии», «Эстетическая медицина», Kosmetik International, «Клиническая дерматология и венерология» и др.), так и издания, рассчитанные на широкий круг читателей («Облик. Esthetic guide», «Метаморфозы», «Ногтевой сервис» и др.).

IX. Современная модель организации оказания кожно-венерологической помощи населению Российской Федерации

С 2010 г. в Российской Федерации осуществляется фрормирование новой модели здравоохранения с преиму- щественным одноканальным фринансированием через систему обязательного медицинского страхования [38, 39]. Основной ее целью является создание условий для равного доступа граждан к качественной медицинской помощи в регионе проживания.

Дерматовенерология как составная часть специализированной медицинской помощи также погружена в систему ОМС. Исключением является медицинская помощь при инфекциях, передаваемых половым путем, фринансирование которой обеспечивается преимущественно за счет региональных бюджетов.

Одним из отличительных признаков новой модели здравоохранения является классификация видов медицинской помощи. В частности, обязательным условием специализированной медицинской помощи стало ее оказание в стационарных условиях (в том числе в условиях дневного стационара при стационарных подразделениях).

Кожно-венерологическая помощь, оказываемая в амбулаторных условиях, отнесена к первичной специализированной медико-санитарной помощи.

В целях повышения доступности помощи населению участковые врачи (терапевты и педиатры), а также врачи общей практики (семейные врачи) наделены правом, при необходимости, осуществлять оказание необходимого объема кожно-венерологической помощи в соответствии с рекомендациями профильной медицинской организации (при отсутствии медицинских показаний для направления в нее).

Кожно-венерологические диспансеры в новой модели здравоохранения сохранили статус головных профильных центров. Их деятельность строго регламентирована порядком оказания медицинской помощи по профилю «Дерматовенерология» (табл. 4) [40].

В отличие от классификации КВД 1951 г. мощность диспансеров, их структура и штатная численность персонала определяются исходя из уровня заболеваемости в регионе, объема проводимой лечебно-диагностической работы и численности обслуживаемого населения. При этом, как правило, на территории региона создается единый диспансер и, при необходимости формируются его фрилиалы.

Врачебные участки, обслуживаемые врачами-дерматовенерологами, так же как и нагрузка на врачей, за период с 1951 г. возросли. Однако до настоящего момента не завершена работа по актуализации норм времени на оказание медицинских услуг одному пациенту при посещении им врача-дерматовенеролога.

Во многом это обусловлено использованием современных информационных технологий при оказании ме-

Таблица 4. Сравнительная характеристика отдельных показателей деятельности кожно-венерологических диспансеров (1951 и 2012 гг.)

Table 4. Comparative characteristics of indicators showing the activity of dermatovenerologic dispensaries (for 1951 and 2012)

\begin{tabular}{|c|c|c|}
\hline Показатели & КВД-1951 & КВД-2012 \\
\hline Коечная мощность & от 10 до 100 коек & не менее 15 коек \\
\hline $\begin{array}{c}\text { Врачебных должностей для оказания стационарной } \\
\text { помощи (врачей-дерматовенерологов) }\end{array}$ & $\begin{array}{c}1 \text { должность на } 3-5 \text { коек } \\
\text { (1,6 койки на } 4000 \text { населения) }\end{array}$ & 1 должность на 15 коек \\
\hline $\begin{array}{c}\text { Врачебных должностей для оказания амбулатор- } \\
\text { ной помощи (врачей-дерматовенерологов) }\end{array}$ & $\begin{array}{c}1 \text { должность на } 16000 \text { населения } \\
\text { (0,25 должности на } 4000 \text { населения) }\end{array}$ & $\begin{array}{c}\text { 1 должность на } 20000 \text { населения } \\
\text { (0,25 должности на } 5000 \text { населения) }\end{array}$ \\
\hline
\end{tabular}

${ }^{1}$ Приведены сведения из приказа Минздрава России от 16 марта 2010 г. № 151н «Об утверждении Порядка оказания медицинской помощи больным дерматовенерологического просиля и больным лепрой (утратил силу с 22 апреля 2013 г.); до завершения работ по проведению соотохронометражных исследований работы врача-дерматовенеролога приведенные данные используются в качестве справочной информации при планировании объемов соответствующего вида медицинской помощи. 
дицинской помощи. Только за последние 10 лет в деятельность кожно-венерологических учреждений внедрен ряд информационных продуктов, включая медицинскую информационную систему, в частности:

- автоматизированная информационная медицинская система лечебно-профилактического учреждения дерматовенерологического профиля «Медицинская инфрормационная система ГНЦД» (адаптированная электронная история болезни);

- информационная аналитическая система с целью обеспечения мониторинга заболеваемости населения Российской Федерации ИППП и заразными кожными заболеваниями, а также оценки ресурсного потенциала профильных медицинских организаций;

- электронный регистр больных хроническими заболеваниями кожи.

Кроме того, фрункционируют телемедицинские терминалы, обеспечивающие информационное взаимодействие фредеральных и региональных врачей-дерматовенерологов как для выработки тактики ведения сложных клинических случаев, так и для реализации образовательных программ.

При этом работа по увеличению нагрузки на специалистов системы здравоохранения и оптимизации их численности будет продолжаться в связи с планируемым к 2025 г. внедрением в деятельность медицинских организаций [41]:

- инфрормационных систем для автоматизации организационных и клинических процессов;

- автоматизированных систем с использованием искусственного интеллекта;

- электронного документооборота.

Другим отличием новой модели здравоохранения является внедрение оплаты медицинской помощи, оказанной в стационарных условиях и в условиях дневного стационара, по клинико-статистическим группам или клинико-профрильным группам [42].
Начиная с 2016 г. в рамках клинико-профильной группы «Дерматология» медицинская помощь оказывается по четырем клинико-статистическим группам (табл. 5) [43]:

- КСГ 27 - редкие и тяжелые дерматозы;

- КСГ 28 - среднетяжелые дерматозы;

- КСГ 29 - легкие дерматозы;

- КСГ 11 - помощь в условиях дневного стационара.

Новые формы оплаты медицинской помощи позволяют оптимизировать неэффективные расходы, уменьшить случаи повторной госпитализации и сместить акцент при организации оказании кожно-венерологической помощи в сторону амбулаторной терапии, в том числе в условиях дневного стационара.

В целом оказание кожно-венерологической помощи К настоящему моменту в большинстве случаев предоставляется в амбулаторных условиях. По состоянию на ноябрь 2017 г., соответствующая лицензия была выдана 9941 организации, более 35 \% которых относятся к частной системе здравоохранения (табл. 6).

Большинство врачей-дерматовенерологов Российской Федерации объединены Общероссийской общественной организацией «Российское общество дерматовенерологов и косметологов» (РОДВК). Свою историю РОДВК ведет с 16 июля 1885 г., когда был одобрен первый устав «Русского сифилидологического и дерматологического общества».

В настоящее время в составе РОДВК состоит более 4,5 тыс. врачей-дерматовенерологов из 69 субъектов Российской Федерации.

РОДВК является учредителем периодического профрильного издания - научно-практического журнала «Вестник дерматологии и венерологии». На протяжении десятилетий журнал служит основным источником актуальной и достоверной информации для врачейдерматовенерологов. Журнал издается на регулярной основе шесть раз в год с тиражом более 4 тыс. экземпляров [44].

Таблица 5. Результаты внедрения КПГ «Дерматология» в 2016 году

Table 5. Results of the introduction of a clinical profile group Dermatology in 2016

\begin{tabular}{|c|c|c|c|c|}
\hline Показатели & КСГ 27 & КСГ 28 & КСГ 29 & КСГ 11 \\
\hline Объем законченных случаев лечения в стационарных условиях, человек & 54833 & 64728 & 43813 & 106942 \\
\hline Тариф, рублей & 35193,8 & 14583,4 & 6989,4 & 13858,5 \\
\hline $\max$ & 129165 & 55223 & 25568 & 48119 \\
\hline $\min$ & 12983 & 5587 & 2419 & 4316 \\
\hline Средняя длительность лечения (общая) в стационарных условиях (дней) & 15 & 10 & 8 & 11 \\
\hline $\max$ & 21 & 18 & 11 & 21 \\
\hline $\min$ & 8 & 7 & 6 & 7 \\
\hline
\end{tabular}

Таблица 6. Сведения об организациях, оказывающих кожно-венерологическую помощь населению Российской Федерации (по данным Росздравнадзора по состоянию на ноябрь 2017 г.)

Table 6. Information on organizations providing dermatological and venereological care to the RF population (according to Roszdravnadzor as at November, 2017)

\begin{tabular}{|c|c|c|c|c|c|c|}
\hline & \multicolumn{2}{|c|}{ Государственные организации } & \multicolumn{2}{|c|}{ Частные организации } & \multicolumn{2}{|c|}{ ВСЕГО } \\
\hline & организации & объекты & организации & объекты & организации & объекты \\
\hline Амбулаторные условия & 3499 & 5541 & 6442 & 7802 & 9941 & 13343 \\
\hline Стационарные условия & 921 & 1309 & 274 & 316 & 1195 & 1625 \\
\hline Прочее & 95 & 124 & 326 & 360 & 421 & 484 \\
\hline
\end{tabular}


Таблица 7. Отдельные показатели развития научно-практического журнала «Вестник дерматологии и венерологии (1958 и 2017 гг.) Table 7. Indicators of the development of the Vestnik Dermatologii i Venerologil journal (in 1958 and 2017)

\begin{tabular}{ccc}
\hline & ВДВ-1958 & ВДВ-2017 \\
\hline Редколлегия журнала & & 19 \\
профессоров & 26 & 1 \\
кандидатов медицинких наук & 7 & 120 \\
\hline Поступление статей (шт./год) & $270-350$ & 96 \\
\hline Ежегодная публикация статей (шт./год) & 180 & 15 \\
\hline Объем возврата статей (\%) & 20 & 6 \\
\hline Периодичность издания (номеров/год) & 12 & $5-6$ \\
\hline Размер номера (печатных листов) & $6-7$ & Менее 6 мес.
\end{tabular}

В период с 1924 по 1930 г. в СССР издавалось только два кожно-венерологических журнала с ежемесячной периодичностью; оба объемами в 6-7 печатных листов [45].

В настоящее время в Российской Федерации наряду с журналом «Вестник дерматологии и венерологии» издается несколько профильных журналов: «Российский журнал кожных и венерических болезней», “Клиническая дерматология и венерология», «Экспериментальная и клиническая дерматовенерология», “Современные проблемы дерматовенерологии, иммунологии и врачебной косметологии» и др. Вместе с тем импакт-срактор журнала «Вестник дерматологии и венерологии» остается наиболее высоким на протяжении длительного периода [46].

\section{X. Перспективные направления развития кожно-венеро- логической помощи}

Таким образом, дерматовенерология по прошествии 100 лет с момента Великой Октябрьской социалистической революции и создания нового государства сохранилась в виде отельной специальности. Во многом это обусловлено решением задач по обеспечению стабильности эпидемиологической ситуации по инфрекциям, передаваемым половым путем, отнесенным к группе социально значимых заболеваний.

Современная дерматовенерология представляет собой динамично развивающуюся специальность, которая активно участвует в реализации основных направлений развития новой модели здравоохранения, преодолевая современные вызовы, в том числе:

1) увеличение продолжительности жизни населения Российской Федерации, что ведет к росту числа случаев заболеваемости новообразованиями кожи, в том числе злокачественными, а также к необходимости профилактики осложнений со стороны кожных покровов при хро- нических соматических заболеваниях (сахарный диабет, венозная недостаточность и др.);

2) рост числа случаев заболеваемости социально значимыми заболеваниями;

3) возрастающая потребность в косметологических процедурах;

4) повышение качества жизни больных, страдающих хроническими дерматозами;

5) ограниченность ресурсов системы здравоохранения на внедрение современных методов лечения в рамках программы госгарантий;

6) глобализация, внедрение современных информационных технологий;

7) ориентация на предиктивные технологии как наиболее эффрективное направление современной науки.

В этой связи основными приоритетами развития научно-исследовательской работы в дерматовенерологии на период до 2025 года определены:

- предиктивная и персонализированная медицина дерматозов и социально значимых заболеваний;

- высокоэффективная геномика, постгеномные технологии в изучении патогенеза дерматозов и диагностики возбудителей ИППП;

- клеточные технологии и регенеративная медицина.

В рамках обеспечения развития медицинской помощи населению планируется в том числе:

- совершенствование кожно-венерологической помощи детям;

- внедрение принципов лекарственного страхования (возмещения) на амбулаторном этапе лечения пациентов, системы “ответственного самолечения» и применения лекарственных препаратов off-label;

- внедрение непрерывной системы повышения квалификации врачей и среднего медицинского персонала, внедрение моделей специалистов (профессиональных стандартов);

- совершенствование статистического наблюдения в области косметологии;

- совершенствование эпидемиологической работы, в том числе по обследованию контактных лиц.

Кроме того, с учетом развития современных медицинских технологий необходимо вернуться к рассмотрению вопроса, поставленного профессором В. А. Рахмановым в 1958 г., об организации лечения ожоговой травмы в условиях кожно-венерологических отделений, а также более широком внедрении в практику кожно-венерологических диспансеров:

- амбулаторной хирургии, в том числе на сосудах;

- организации оказания помощи больным с псориатическим артритом;

- медицинской помощи больным со злокачественными новообразованиями кожи и химиотерапии злокачественных новообразований лимфоидной ткани. 


\section{Литература/References}

1. Лапышев Д. А. Временные микологические стационары на базе участковых больниц как организационный фактор в борьбе с трихомикозами на селе / Труды Второго Всероссийского съезда дерматовенерологов. Горький: Волго-Вятское книжное издательство, 1968:43-44. [Lapyshev D. A Temporary mycological hospitals on the basis of district hospitals as an organizational factor in the fight against trichomycosis in the countryside / Proceedings of the Second All-Russian Congress of Dermatovenerologists. Gorky: Volgo-Vyatsky book publishing house, 1968:43-44.]

2. Приказ Минздрава РСФСР, Минсельхоза РСФСР и Минжилкомхоза РСФСР от 26 декабря 1985 г. № 884/20пр/629 «0 мерах по усилению борьбы с дерматофитиями в РСФСР». [Order of the RSFSR Ministry of Health, the RSFSR Ministry of Agriculture and the RSFSR Ministry of Housing and Communal Services issued December 26, 1985, no. 884 / 20pr / 629, On measures for strengthening the fight against dermatophytys in the RSFSR.]

3. Приказ Минздрава СССР от 22 июня 1983 г. № 750. [Order of the USSR Ministry of Health issued June, 1983, no. 750.]

4. Приказ Минздрава СССР от 27 декабря 1983 г. № 1470. [Order of the USSR Ministry of Health issued December, 27, 1983, no. 1470.]

5. Приказ Минздрава России от 21 марта 2003 г. № 115 «0 внесении дополнений в приказ Минздрава России от 27 августа 1999 г. № 337 "О номенклатуре специальностей в учреждениях здравоохранения Российской Федерации"». [Order of the RF Ministry of Health issued March 21, 2003, no. 115 On Amendments to the Order of the RF Ministry of Health from August 27, 1999, no. 337 into The Nomenclature of Specialities in the RF Health Care.]

6. Приказ Минздрава России от 21 марта 2003 г. № 116 «0 враче клиническом миколог и враче - лабораторном микологе». [Order of the RF Ministry of Health issued March 21, 2003, no. 116 About the doctor-clinical mycologist and physician-laboratory mycologist.]

7. Приказ Минздрава России от 28 января 2004 г. № 20 «0 создании научно-методического микологического центра Минздрава России». [Order of the RF Ministry of Health issued January 28, 2004, no. 20 On the establishment of the RF Ministry of Health scientific and methodological mycological centre.]

8. Постановление Совнаркома СССР от 10 июля 1923 г. «0 мерах борьбы с проказой». [Resolution of the USSR Council of People's Commissars issued July 10, 1923 On measures for combating leprosy.]

9. Постановление Совета Министров СССР от 6 ноября 1947 г. № 16389 «0 создании Всесоюзного научно-исследовательского института по изучению лепры на базе Астраханского клинического лепрозория». [Resolution of the USSR Council of Ministers issued November 6, 1947, no.16389 On the establishment of the All-USSR Scientific Research Institute for the Study of Leprosy on the basis of the Astrakhan Clinical leprosarium.]

10. Приказ Минздрава СССР от 14 декабря 1990 г. № 483 «0б утверждении инструкции по борьбе с лепрой». [Order of the USSR Ministry of Health issued December 14, 1990, no. 483 On the approval of instructions for combating leprosy.]

11. Захарова Ф. Г. Состояние и задачи борьбы с венерическими и кожными заболеваниями в СССР/ Труды V Всесоюзного съезда дерматовенерологов. Ленинград: Медгиз, 1961:9-15. [Zakharova F. G. The state and tasks of combating venereal and skin diseases in the USSR / Proceedings of the Fifth All-Union Congress of Dermato-Venereologists. Leningrad: Medgiz, 1961: 9-15.]

12. Студницин А. А., Туранов Н. М., Артамонова Л. А., Никитина Н. В. Основные мероприятия по улучшению качества научной и практической работы дерматовенерологических учреждений / Труды V Всесоюзного съезда дерматовенерологов. Ленинград: Медгиз, 1961:15-21. [Studnitsin A. A, Turanov N. M., Artamonova L. A., Nikitina N. V. The main measures to improve the quality of scientific and practical work of dermato-venereological institutions / Proceedings of the Fifth All-Union Congress of Dermato-Venereologists. Leningrad: Medgiz, 1961:15-21.]
13. Приказ Минздрава СССР от 28 мая 1962 г. № 265 «0 мероприятиях по снижению заболеваемости лепрой в СССР». [Order of the USSR Ministry of Health issued May 28, 1962, no. 265 On measures for reducing the incidence of leprosy in the USSR.]

14. Приказ Минздрава СССР от 29 сентября 1971 г. № 721 «0 дополнительных мероприятиях по усилению борьбы с лепрой в СССР». [Order of the USSR Ministry of Health issued September 29, 1971, no. 721 On additional measures for strengthening the fight against leprosy in the USSR.]

15. Приказ Минздрава СССР от 14 декабря 1990 г. № 483 «0б утверждении инструкций по борьбе с лепрой». [Order of the USSR Ministry of Health issued December 14, 1990, no. 483 On the approval of instructions for combating leprosy.]

16. Постановление Совета Министров СССР от 10 августа 1962 г. № 820. [Resolution of the USSR Council of Ministers issued August 10, 1962, no. 820.]

17. Приказ Минздрава СССР от 30 августа 1962 г. № 422 «Об улучшении материального обеспечения больных лепрой». [Order of the USSR Ministry of Health issued August 30, 1962, no. 422 On improving the material support of leprosy patients.]

18. Дуйко В. В. Основные направления организации медико-социальной помощи больным лепрой в современных условиях: Автореф. дис. ... д-ра мед. наук, 2013. [Duyko V. V. The main directions of the organization of medical and social assistance to patients with leprosy in modern conditions / The dissertation author's abstract on the competition of a scientific degree of the doctor of medical sciences, 2013.]

19. Кожевников П. В. Состояние и задачи профилактики и лечения кожных болезней / Труды V Всесоюзного съезда дерматовенерологов. Ленинград: Медгиз, 1961:26-30. [Kozhevnikov P. V. State and objectives of prevention and treatment of skin diseases / Proceedings of the Fifth All-Union Congress of Dermato-Venereologists. Leningrad: Medgiz, 1961:26-30.]

20. Ласс Д. И., Поликарпова М. Г. Уход за кожей лица. Пособие для работников косметических кабинетов. Москва: Издательство Министерства коммунального хозяйства РСФСР, 1956:192. [Lass D. I., Polikarpova M. G. Skin Care. A Handbook for Cosmetic Cabinet Workers. Moscow: Publishing House of the Ministry of Communal Services of the RSFSR, 1956:192.]

21. Приказ Минздрава СССР от 28.12.1982 № 1290 «0 мерах по улучшению косметологической помощи населению». [Order of the USSR Ministry of Health issued December, 28, 1982, no. 1290 On measures for improving the cosmetic skin care for the population.]

22. Приказ Минздрава России от 3 ноября 1989 г. № 165 «0 создании хозрасчетного Научно-практического объединения «Косметология» Минздрава РСФСР». [Order of the RF Ministry of Health issued November 3, 1989, no. 165 On the establishment of a self-supporting Scientific and Practical Association 'Cosmetology' of the RSFSR Ministry of Health.]

23. Приказ Минздрава России от 28 августа 1998 г. № 261 «0б утверждении Устава федерального государственного унитарного предприятия «Институт пластической хирургии и косметологии» Министерства здравоохранения Российской Федерации. [Order of the RF Ministry of Health issued August 28, 1998, no. 261 On the Approval of the Statute of the RF Ministry of Health Institute for Plastic Surgery and Cosmetology.]

24. Панова О. С. Теоретические и прикладные аспекты современной дерматокосметологии: Автореф. дис. ... д-ра мед. наук. Москва, 2001:44. [Panova 0. S. Theoretical and applied aspects of modern dermatocosmetology / The dissertation author's abstract on competition of a scientific degree of the doctor of medical sciences. Moscow, 2001:44.]

25. Закон Российской Федерации от 28 июня 1991 г. № 1499-1 «0 медицинском страховании граждан в Российской Федерации». [RF Law issued June 28, 1991, no. 1499-1 On the medical insurance of citizens in the Russian Federation.]

26. Кубанова А. А., Панова О. С., Мартынов А. А. Организационноправовые основы врачебной косметологии и эстетической медицины. 
Вестник дерматологии и венерологии. 2008;2:15-22. [Kubanova A. А., Panova 0. S., Martynov A. A. Organizational and legal bases of medical cosmetic skin care and aesthetic medicine. Vestnik Dermatologii i Venerologii. 2008;2:15-22.]

27. Письмо Росздравнадзора от 15 апреля 2005 г. № 01-3213/05. [Letter of Roszdravnadzor issued April 15, 2005, no. 01-3213 / 05.]

28. Приказ Минздравсоцразвития России от 13 октября 2005 г. № 633 «0б организации медицинской помощи». [Order of the RF Ministry of Healthcare and Social Development issued October 13, 2005, no. 633 On the organization of medical care.]

29. Приказ Минздравсоцразвития России от 7 октября 2005 г. № 627 «0б утверждении единой номенклатуры государственных и муниципальных учреждений здравоохранения». [Order of the RF Ministry of Health and Social Development issued October 7, 2005, no. 627 On the Approval of a Nomenclature of State and Municipal Health Care Institutions.]

30. Перечень работ и услуг по косметологии, относящихся к медицинской деятельности (Учрежден Федеральной службой по надзору в сфере здравоохранения и социального развития). Менеджмент качества в ссрере здравоохранения и социального развития, 2008;3. [List of works and services in cosmetic skin care considered medicine activity (Approved by the Federal Service for Supervision in Health and Social Development). Quality Management in Health Care and Social Development. 2008;3.]

31. Приказ Минздравсоцразвития России от 23 апреля 2009 г. № 210н «0 номенклатуре специальностей специалистов с высшим и послевузовским медицинским и фармацевтическим образованием в сфере здравоохранения Российской Федерации». [Order of the RF Ministry of Health and Social Development issued April 23, 2009, no. 210n On the nomenclature of specialities with higher and postgraduate medical and pharmaceutical education in the healthcare of the Russian Federation.]

32. Приказ Минздрава России от 7 октября 2015 г. № $700 \mathrm{H} « 0$ номенклатуре специальностей с высшим и послевузовским медицинским и фармацевтическим образованием в сфрере здравоохранения Российской Федерации». [Order of the RF Ministry of Health issued October 7, 2015, no. 700n On the nomenclature of specialities with higher and postgraduate medical and pharmaceutical education in the Russian Federation Healthcare System.]

33. Приказ Минздравсоцразвития России от 13 декабря 2010 г. № 1099 «0б утверждении устава федерального государственного учреждения "Государственный научный центр дерматовенерологии и косметологии" Министерства здравоохранения и социального развития Российской Федерации в новой редакции". [Order of the RF Ministry of Health Care and Social Development issued December 13, 2010, no. 1099 On approval of the Statute of the Federal State Institution 'State Scientific Centre for Dermatovenereology and Cosmetology'.]

34. Приказ Минздравсоцразвития России от 27 января 2010 г. № 32 «0 внесении изменений в приказ Минздравсоцразвития России от 26 ноября 2004 г. № 283 "0 главных внештатных специалистах-экспертах Министерства здравоохранения и социального развития Российской Федерации"». [Order of the RF Ministry of Health Care and Social Development issued January 27, 2010, no. 32 On Amendments to the Order of the RF Ministry of Health Care and Social Development issued November 26, 2004, no 283 'On the external experts of the RF Ministry of Health Care and Social Development'.]

35. Приказ Минздрава России от 8 октября 2015 года № 707н «0б утверждении Квалификационных требований к медицинским и фармацевтическим работникам с высшим образованием по направлению подготовки "Здравоохранение и медицинские науки"». [Order of the RF Ministry of Health Care issued October 8, 2015, no. 707n On the approval of qualification requirements for medical and pharmaceutical employees with higher education in the field of Health and Medical Sciences.]

36. Приказ Минздравосоцразвития России Министерства от 18 апреля 2012 г. № 381н «0б утверждении порядка оказания медицинской помощи населению по профилю "Косметология" ». [Order of the RF Ministry of Health Care and Social Development issued April 18, 2012, no. 381n On the approval of a procedure for providing medical care to the population in the field of Cosmetology.]

37. Vademecum впервые подсчитал объем рынка «уколов красоты». Vademecum. 2017;3(138). [Vademecum has calculated the volume of the filler injection market for the first time. Vademecum. 2017;3(138).]

38. Федеральный закон от 21 ноября 2011 г. № 323-Ф3 «0б основах охраны здоровья граждан в Российской Федерации». [Federal Law dated November 21, 2011, no. 323-FL On the fundamentals of protecting the health of citizens in the Russian Federation.]

39. Федеральный закон от 29 ноября 2010 г. № 326-Ф3 «0б обязательном медицинском страховании в Российской Федерации». [Federal Law dated November 29, 2010, no. 326-FL On compulsory medical insurance in the Russian Federation.]

40. Приказ Минздрава России от 15 ноября 2012 г. № 924н «0б утверждении порядка оказания медицинской помощи населению по профилю "Дерматовенерология" ». [Order of the RF Ministry of Health issued November 15, 2012, no. 924n On the approval of a procedure for providing medical care to the population in the field of dermatovenereology.]

41. Протокол заседания Совета по стратегическому развитию и приоритетным проектам от 21 марта 2017 г. № 1. http://kremlin.ru/acts/ assignments/orders/54266 [Minutes of the Council for Strategic Development and Priority Projects meeting, March 21, 2017 No. 1. (http://kremlin.ru/acts/ assignments/orders/54266).]

42. Мартынов А. А., Стадченко Н. Н., Власова А. В. 0 новой модели финансирования и обеспечения качества дерматовенерологической помощи. Вестник дерматологии и венерологии. 2016;6:10-19. [Martynov А. А., Stadchenko N. N., Vlasova A. V. On a new financing and quality assurance model of dermatovenereological care. Vestnik Dermatologii $i$ Venerologii. 2016:6:10-19.]

43. Мартынов А. А., Власова А. В., Основные направления стратегического развития дерматовенерологической помощи. Фарматека. Дерматология/Аллергология. 2017;2:56-63. [Martynov A. A., Vlasova A. V. The main directions for the strategic development of dermatovenereological care. Pharmateka. Dermatology/Allergology. 2017;2:56-63.]

44. Кубанова А. А., Кубанов А. А., Карамова А. Э. Журнал «Вестник дерматологии и венерологии» - videre majus guiddam. K 90-летней годовщине издания журнала. Вестник дерматологии и венерологии. 2014:6:20-25. [Kubanova A. A., Kubanov A. A., Karamova A. E. The journal "Vestnik Dermatologii i Venerologii" — videre majus guiddam. To the 90th anniversary of the journal. Vestnik Dermatologii $i$ Venerologii. 2014;6:20-25.]

45. Кожевников П. В. Отчет редакции журнала «Вестник дерматологии и венерологии / Труды V Всесоюзного съезда дерматовенерологов. Ленинград: Медгиз, 1961:149-153. [Kozhevnikov P. V. Report of the editorial board of the Bulletin of Dermatology and Venereology journal. Proceedings of the 5th All-USSR Congress of Dermato-Venereologists. Leningrad: State Publishing House of Medical Literature "Medgiz". 1961:149-153.]

46. Кубанова А. А., Кубанов А. А., Карамова А. Э. Направления развития журнала «Вестник дерматологии и венерологии». Вестник дерматологии и венерологии. 2014;6:20-25. [Kubanova A. A., Kubanov A. А., Karamova A. E. Directions for the development of the Vestnik Dermatologii i Venerologii journal. Vestnik Dermatologii i Venerologii. 2014;6:20-25.] 


\section{Информация об авторах}

Анна Алексеевна Кубанова - д.м.Н., профессор, академик РАН, директор Государственного научного центра дерматовенерологии и косметологии Министерства здравоохранения Российской Федерации

Андрей Александрович Мартынов* - д.м.н., профессор, ведущий научный сотрудник отдела дерматологии Государственного научного центра дерматовенерологии и косметологии Министерства здравоохранения Российской Федерации; e-mail: aamart@mail.ru

Анна Васильевна Власова - к.м.н., доцент касредры Первого Московского государственного медицинского университета имени И.М. Сеченова Министерства здравоохранения Российской Федерации

\section{Information about the authors}

Anna A. Kubanova - Dr. Sci. (Medicine), Prof., Academician of the Russian Academy of Sciences, Head of the State Research Center of Dermatovenereology and Cosmetology, Ministry of Healthcare of the Russian Federation

Andrey A. Martynov* — Dr. Sci. (Medicine), Prof., Leading Scientific Researcher, Department of Dermatology, State Research Center of Dermatovenereology and Cosmetology, Ministry of Healthcare of the Russian Federation; e-mail: aamart@mail.ru

Anna V. Vlasova - Cand. Sci. (Medicine), Associate Professor, I. M. Sechenov First Moscow State Medical University of the Ministry of Health of the Russian Federation (Sechenov University) 